\title{
Mediating the agency of distant others : Proper distance in fair trade communication on Facebook
}

\section{Polynczuk-Alenius, Kinga}

2018-03

Polynczuk-Alenius, K 2018 , ' Mediating the agency of distant others : Proper distance in fair trade communication on Facebook ' , International Journal of Cultural Studies, vol. 21 , no. 2 , pp. 155-172 . https://doi.org/10.1177/1367877916667778

http://hdl.handle.net/10138/308410

https://doi.org/10.1177/1367877916667778

unspecified

acceptedVersion

Downloaded from Helda, University of Helsinki institutional repository.

This is an electronic reprint of the original article.

This reprint may differ from the original in pagination and typographic detail.

Please cite the original version. 
Kinga Polynczuk-Alenius

Faculty of Social Sciences

Media and Communication Studies

P.O. Box 54, Unioninkatu 37

FI-00014 University of Helsinki, Finland

kinga.polynczuk@helsinki.fi

\section{Mediating the agency of distant others: Proper distance in fair trade communication on Facebook}

\section{ABSTRACT}

To introduce economic justice into global trade, fair trade organizations strive to

'shorten the distance' between producers and consumers through mediation. This article problematizes the idea of 'shortening the distance' through the notion of maintaining the 'proper distance' in representing distant others (Silverstone, 2003, 2007). This perspective is used in narratological analysis of the content that fair trade organizations curate on their Facebook pages to represent Southern producers. The two studied organizations are: 1) Fairtrade Finland, a non-governmental organization (NGO); 2) Pizca del Mundo, a commercial brand in Poland. This article identifies the discursive and narrative forms of mediated agency that are offered to producers. The analysis revealed that Fairtrade Finland utilized Facebook to extend the narrative of producers as active subjects. By using the affordances of Facebook, Pizca del Mundo increased the 
mediated agency of producers but problematized the maintenance of the proper distance in their representations.

\section{Keywords}

fair trade, proper distance, agency, distant other, mediation, narratology, Facebook

Fair trade is an alternative trade model that was developed to correct the economic injustices embedded in the post-colonial structures of trade between the Global South and the Global North (Brown, 2007; Le Velly, 2007; Moberg and Lyon, 2010). To that end, fair trade strives to 'shorten the distance' between the two ends of the commodity chain by reducing the number of intermediaries (Brown, 2007; Fisher, 2007; Lyon, 2006; Shreck, 2005). Fair trade assumes that a shorter supply chain inevitably entails a more ethical relationship, thus leading to the just treatment of Southern producers (Goodman, 2004; Low and Davenport, 2007; Raynolds, 2002, 2008; Shreck, 2005). I problematize this presumption by approaching the idea of shortening the distance as a process of mediation whereby producers, as distant others, appear to consumers predominantly in media content (see Silverstone, 2007). This reconceptualization reclaims representation as the core means of constructing ethical relationships with distant others (Orgad, 2012; Orgad and Seu, 2014) and emphasises the imperative of 'proper distance', that is, the demand to present distant others in both their shared 
humanity (similarity) and their differences (Silverstone, 2003, 2007). Here, similarity is understood as the agency of producers (see Orgad and Seu, 2014), whereas difference denotes the adverse circumstances that shape this agency (see Raghuram et al., 2009). Arguably, this mode of representation enables empathy with and greater understanding of distant others (see Silverstone, 2007).

The Facebook pages of fair trade organizations are analysed as communication channels for shortening the distance between producers and consumers in a manner that respects the principle of proper distance. The affordances of Facebook, such as interactivity and the continuous, nearly unrestricted flow of easily produced content, appear to be conducive to this mode of representation. However, social media remains understudied as an alternative channel of fair trade communication. To bridge this gap, the study asks: How is proper distance mediated in the representations of Southern producers deployed by fair trade organizations on their Facebook pages?

The analysis concentrates on two fair trade actors: Fairtrade Finland, a nongovernmental organization (NGO) and a member of Fairtrade International, and Pizca del Mundo, a commercial brand in Poland. I have selected organizations that have different status in the market economy (a non-profit NGO vs. a private business), varying degrees of popularity on Facebook (44,500 fans vs. 1,200 fans) and different countries of origin (well-established fair trade market and advanced economy of Finland 
versus the feeble demand for fair trade products in the less prosperous Polish society) to map the relevance of maintaining proper distance in fair trade representations. The study of organizations that represent two relatively small fair trade markets is aimed at providing a counterweight to the plethora of studies conducted in the Anglosphere in order to elucidate alternative trajectories to the cultural politics of mainstreaming and celebritization that guide fair trade communication in the UK (see Goodman, 2010).

I first problematize the idea of shortening the distance between producers and consumers from the perspective of 'proper distance' and then re-read the criticism of representations of Southern producers in fair trade marketing accordingly.

Subsequently, I examine the significance of producers' agency in the fair trade system and the potential of social media in the context of its articulation. I then present an overview of the research material and methods used in this study. Finally, I report the results of the narratological analysis, and discuss them from the perspective of proper distance.

\section{Fair trade, representation and 'proper distance'}

Fair trade strives to achieve economic justice by correcting the distortions of conventional global trade (Brown, 2007; Le Velly, 2007; Moberg and Lyon, 2010). This strategy involves the reversal of commodity fetishism, that is, the misperception of trade as a relationship between money and purchasable goods, which ignores the moral 
principles and obligations that govern interpersonal relations between Southern producers and Northern consumers (Fisher, 2007; Hudson and Hudson, 2003; Moberg and Lyon, 2010). The central tactic employed to de-fetishize commodities is 'shortening the distance' between producers and consumers (Fisher, 2007; Goodman, 2004; Le Velly, 2007; Lyon, 2006; Shreck, 2005). 'Shortening the distance' refers to both the deliberate shrinking of commodity chains and to the assumption that a shorter chain automatically entails a social connection with and obligation towards Southern producers (Goodman, 2004; Low and Davenport, 2007; Raynolds, 2002, 2008; Shreck, 2005). As pervasive as the idea is in industry and in the academic discourse on fair trade, this double meaning is problematic because it overlooks the significance of the practices of mediation and representation in the construction of empathic and moral relationships with distant others.

Mediation refers to the role of media content in constructing the meaningfulness and value of people and events in social life (Silverstone, 2002: 761). The term 'shortening the distance' can be translated as mediation in the vocabulary of media and communication studies because content produced and curated by fair trade organizations provides an interface where producers and consumers can 'meet' (see Fisher, 2007). Representation is a powerful tool of mediation, which nourishes the 'global imagination' by supporting people's ability to empathize with one another (Orgad, 2012). According to Silverstone (2003, 2007), the feeling of responsibility 
towards and understanding of distant others can be awakened only if representations maintain the 'proper distance' between distant others and the audience.

The concept of proper distance posits that to encourage consumers to act on the realities behind representations, distant others must be presented in both shared humanity and difference (Silverstone, 2008: 91). This vague definition points to the relative volatility of proper distance which must be determined on a case-by-case basis (Silverstone, 2003). Nevertheless, the concept powerfully repudiates trivial (mis-)understandings of distant others, which are founded on one-dimensional, unequivocal representations. To transform the elusive notion of proper distance into an analytical tool that is applicable to the study of fair trade representations, I link 'shared humanity' (similarity) to the agency of producers as active subjects who try to sustain their living through hard work and participation in the global marketplace (Adams and Raisborough, 2008; Luetchford, 2008). Here, I follow the large body of humanitarian communication research in claiming that representing distant others as active agents rather than passive victims facilitates the development of empathy (e.g., Chouliaraki, 2006; Linklater, 2007; Orgad and Seu, 2014). Further, 'difference' refers to the conspicuously distinctive appearance of fair trade producers but primarily to unveiling their material deprivation, which is shaped by the colonial structures of global trade (see Brown, 2007). These exploitative trading relationships and the resulting poverty constitute the context of producer agency (Raghuram et al., 2009). By emphasising the connections between prosperity in the 
North and poverty in the South as the context that significantly shapes the agency of producers, I attempt to mitigate the Northern-centrism inherent in the notion of proper distance. Although proper distance assumes the responsibility of the mediators for the marginalized, it is in fact predicated on the obligation towards the audience to render distant others comfortably understandable (Silverstone, 2003: 476; for other points of criticism see Dayan, 2007; Frosh, 2011; Wright, 2011).

The academic literature is often very critical of fair trade communication because of its tendency to commodify and romanticize Southern producers through the deployment of exoticized and stereotypical representations that portray producers as humble, grateful and contented peasants working in idyllic nature (Berlan, 2008; Goodman, 2004; Wright, 2004). I suggest that such 'failed' fair trade representations can be re-read from the perspective of proper distance, in which 'commodification' is understood as an inadequate representation of the producers' agency ('sameness') and 'romanticization' results from the insufficient elaboration of the circumstances that shape this agency ('difference'). First, in commodification, production processes, and by extension producers, are misrepresented as the attributes of purchasable items (Goodman, 2004: 902; see also Dolan, 2008; Fisher, 2007; Lyon, 2006; Varul, 2008). From the perspective of proper distance, conflating Southern producers with commodities erases their agency as 'makers' of products and instead 'subsumes' them into a product as its property (see Wright, 2004). Second, Southern producers might appear to consumers 
merely as a part of the faraway landscapes because they are always presented at work and surrounded by exotic nature (Lyon, 2006: 487; Varul, 2008). Particularly when it is coupled with a commonly deployed imagery of smiling people 'like us' (Ramamurthy, 2012), this mode of representation romanticizes producers by obscuring the oppressive trade system that causes the differences in their life situations (see Dogra, 2012).

\section{Agency and the promise of social media}

Fair trade is constructed around the agency of Southern producers (see Bryant and Goodman, 2004; Dolan, 2008). Indeed, its ultimate objective is that producers would seize control of the relevant commodity chains, thereby strengthening their agency and voice in the structures of global trade (Brown, 2007). In the daily operations of the fair trade system, producers are addressed as masters of their own destiny who endeavour to escape poverty (Adams and Raisborough, 2008), and consciously invest financial premium in the development of their communities (see Dolan, 2008; Tallontire, 2009). This participatory model endows Southern producers with both agency and voice (Dolan, 2008). The core argument of this paper is that fair trade communication would benefit from incorporating the agency and viewpoints (see Silverstone, 2007) of producers in their representations. The internet and social media are possible arenas for Southern producers to influence and even dictate new modes of representation, which 
would take into account Spivak's (1993: 70) distinction between the two meanings of representation: as 're-presenting', that is, depicting, and as 'speaking for'.

Although the lack of status and linguistic capital might inhibit the participation and voices of underprivileged groups in the representational practices of the institutionalized gatekeeper media (see Spivak, 1993), the internet seemingly renders these resources irrelevant (Mitra, 2004; Mitra and Watts, 2002; Silverstone, 2007: 42). Arguably, the internet provides the 'language' and technology to empower the marginalized to speak for themselves (Mitra, 2001, 2004). Loosened gatekeeping practices, ease of content production and interactivity are often referred to as the features of the internet that are conducive to the 'decentralization' and democratization of voice (Chouliaraki, 2011: 367; see also Chouliaraki, 2010; Madianou, 2013; Mitra, 2001, 2004; Silverstone, 2007). Social media provides a case in point: through enabling the easy production and sharing of content, it facilitates the participation of marginal voices (Madianou, 2013: 250). Facebook, with its 1.5 billion users worldwide, appears to have a particularly high potential to host a multitude of diverse voices.

However, several accounts claim that the internet might in fact fail to fulfil the promise of democratizing voice (Madianou, Longboan and Ong, 2015; Silverstone, 2007) and that decentralization usually pertains to the increased participation of ordinary Northern voices (Chouliaraki, 2011: 367). Even if the voices of distant others do emerge, they 
usually belong to those who are better off, which effectively inhibits the participation of the most marginalized groups (Madianou, Longboan and Ong, 2015). Moreover, the nature of the internet as a communication technology is such that the (marginalized) voice can be switched off at any time (Silverstone, 2003).

Despite these drawbacks, Facebook is worth studying as a channel for shortening the distance between producers and consumers for two primary reasons. First, the affordances of Facebook favour the enhancement of conventional producers' representations through potentially facilitating a direct connection between producers and consumers. Facebook also allows for the context that shapes producer's agency to be elaborated because of its nearly unlimited space and continuous mode of communication. Second, although it would be erroneous to assume that an electronically mediated connection implies a simultaneous social connection (see Silverstone, 2003), the repetitive presence on a Facebook wall of representations of distant others could potentially facilitate the cumulative building of a relationship and the emergence of a knowledge-based connection (see Frosh, 2011; Le Velly, 2007).

\section{Materials and methods}

This paper analyses the content of the official Facebook pages of two fair trade organizations: Fairtrade Finland and Pizca del Mundo. Fairtrade Finland is a non-profit organization that was established in 1998 to coordinate the use of the Fairtrade label in 
Finland. Hence, Fairtrade Finland is not directly involved in sales; instead, it promotes and regulates the implementation of Fairtrade standards among Finnish companies. Fairtrade Finland's Facebook page has been 'liked' by over 44,500 people. In a country of 5.5 million people, this relative popularity might be attributed to the high awareness of fair trade in the society ( $83 \%$ in 2005) (Krier, 2008) and the wide availability of over 1,700 Fairtrade-certified products (Reilu kauppa, 2016). This reputation is also reflected in the incremental growth in Fairtrade sales, which reached 173.5 million euros in 2016 (Reilu kauppa, 2016).

Pizca del Mundo was established in 2012 as a pioneering commercial brand to offer fair trade products on the Polish market. Unlike other Polish fair trade organizations, Pizca del Mundo purchases ingredients directly from Southern producers. On its Facebook page, the brand describes its mission in terms of 'providing Polish consumers with the opportunity to purchase high-quality ethical products... striv[ing] to contact the primary producers and shorten the supply chain, while maintaining the fair partnership standards which are the best guarantee of stable and sustainable development' (Pizca del Mundo, n.d.). Pizca del Mundo's Facebook page has been 'liked' by just over 1,200 users, which reflects the difficulty in developing the fair trade market in Poland. Indeed, the latest available estimates indicated sales of 2.1 million euros in 2010 (Gazeta Wyborcza, 2012), while only 35\% of Polish consumers declared any interest in fair trade (Radziukiewicz, 2013). 
Narratology, a "theory of narratives, narrative texts, [and] images ... that "tell a story"' (Bal, 1997: 3), was employed to analyse the Facebook pages of Fairtrade Finland and Pizca del Mundo. This method is relevant because the curation of social media content is often described as 'digital storytelling', namely, a widely distributed capacity to represent the world enabled by a publicly accessible communication infrastructure (Couldry, 2008: 374). To investigate the mediated agency of Southern producers, I selected posts that contained their visual or textual representations added between August 2013 and September 2015. This material comprised 120 posts: 70 posts were retrieved from Fairtrade Finland's Facebook page, and 50 posts were obtained from Pizca del Mundo’s Facebook page.

The content that each organization used to represent Southern producers was treated as a single narrative that was composed of a variety of 'stories' about distant others, which were presented in the individual posts. First, in treating the organizations as narrators in their capacity to curate content, I examined their position in the narratives (Bal, 1997). Second, the discourse - the manner in which the events are presented (Culler, 2001: 183) - was inspected, which led to the identification of Southern producers as the collective subject of the narratives and the positioning of other actors as helpers. I also determined that subjects and helpers were revealed by the discourse of the narrative, not by the plot. Thus, in this paper, the agency of Southern producers in actively shaping their everyday realities is termed 'discursive agency'. Third, I ascertained whether and 
how Southern producers could motivate and influence the process of narration through 'narrative agency'. Three forms of narrative agency_acting, looking and speaking (Bal, 1997) — were mapped onto the analysed material. Fourth, the voices, that is, the ability of the agents to speak in their own words, of Southern producers were identified in three posts. An overview of three forms of mediated agency — discursive agency, narrative agency and voice - is provided in Table 1 .

\begin{tabular}{|l|l|l|l|}
\cline { 2 - 4 } \multicolumn{1}{c|}{} & Discursive agency & Narrative agency & Voice \\
\hline in the narrative & $\begin{array}{l}\text { producers actively } \\
\text { shape their lives, } \\
\text { but do not influence } \\
\text { narration }\end{array}$ & $\begin{array}{l}\text { producers motivate } \\
\text { narration through } \\
\text { looking, acting and } \\
\text { speaking } \\
\text { (expressing } \\
\text { viewpoints) }\end{array}$ & $\begin{array}{l}\text { producers are } \\
\text { internal narrators, } \\
\text { speaking in their } \\
\text { own words }\end{array}$ \\
\hline $\begin{array}{l}\text { Level of narrative } \\
\text { representation }\end{array}$ & $\begin{array}{l}\text { discourse (manner } \\
\text { of telling the story) }\end{array}$ & $\begin{array}{l}\text { narration (process } \\
\text { of telling the story) }\end{array}$ & $\begin{array}{l}\text { narration (process } \\
\text { of telling the } \\
\text { story) }\end{array}$ \\
\hline $\begin{array}{l}\text { (content generated } \\
\text { by fair trade } \\
\text { organizations) }\end{array}$ & $\begin{array}{l}\text { content generated } \\
\text { by producer } \\
\text { organizations } \\
\text { accompanied by } \\
\text { fair trade } \\
\text { organizations' } \\
\text { commentary; } \\
\text { speech) }\end{array}$ & $\begin{array}{l}\text { siewpoints } \\
\text { expressed in } \\
\text { reported speech }\end{array}$ & - \\
\hline $\begin{array}{l}\text { Present in the } \\
\text { narrative of the self- } \\
\text { determining }\end{array}$ & $\checkmark$ & & \\
\hline
\end{tabular}




\begin{tabular}{|l|l|l|l|}
\hline producers & & & \\
\hline $\begin{array}{l}\text { Present in the } \\
\text { narrative of the } \\
\text { narrating producers }\end{array}$ & & $\checkmark$ & $\checkmark$ \\
\hline
\end{tabular}

Table 1. Three forms of mediated agency

\section{The narratives of fair trade producers}

The narratological analysis demonstrated that Fairtrade Finland and Pizca del Mundo used distinctive narratives to represent Southern producers. They articulated their narrative roles differently, and they offered Southern producers varied forms of mediated agency. In the following section, I will discuss the narrative of the selfdetermining producers used by Fairtrade Finland and the narrative of the narrating producers employed by Pizca del Mundo.

\section{The narrative of the self-determining producers}

The narrative employed by Fairtrade Finland positions producers as a collective subject pursuing the betterment of its livelihood with the help of the Fairtrade system and consumers. Although Fairtrade Finland is one of the characters in the story, the narrative is presented as if it is told by an external narrator. The narrator remains covert and appears impartial because the first person is not used except in one sentence: 'We [Fairtrade]... disseminate information on why poor farmers must allow their children to 
go to school, and [we] support education by paying farmers an adequate price for their products'.

This narrative offers discursive agency to producers, which resides in the stories that represent them as active agents who are capable of determining the course of the development of their communities. The narrative revolves around the Fairtrade premium and its use by various producer co-operatives:

Fairtrade cotton farmers are paid a guaranteed price per harvest, and the Fairtrade premium on whose use co-operatives decide themselves. In Senegal, farmers have used their Fairtrade premium to, for example, build and furnish schools and health centres, and [buy] school supplies for children. (Reilu kauppa, 3 March 2014)

The textual descriptions of the producers as active agents are accompanied by visual representations that range from rare product photos and close-ups of working hands (for a critique of this mode of representation see Wright, 2004) to much more common photographs depicting the everyday operations of co-operatives to the portraits of individual producers, which are the most frequent. The situations and locations depicted in the photos are almost always described (e.g., 'The picture of a meeting of the Fairtrade coffee farmers from Waslala, Nicaragua', see Figure 1), and the captions of individual portraits usually indicate the names of the depicted producers (e.g., 'In the 
photo, Finca En Antojon from a banana farm in Colombia'). By representing producers as embodied subjects, diligent workers and self-determining agents, Fairtrade Finland positions them as the protagonists in the narrative (Bal, 1997).

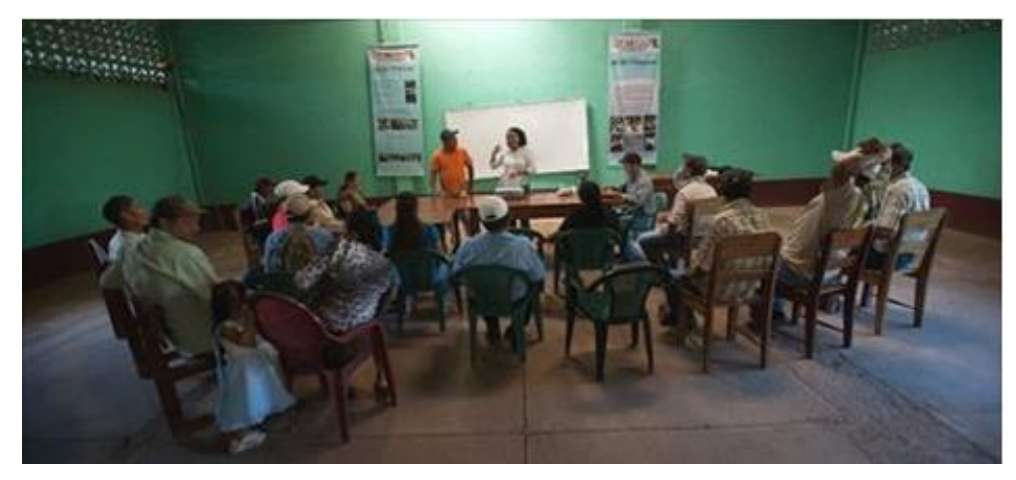

Figure 1. The picture of a meeting of the Fairtrade coffee farmers from Waslala, Nicaragua (copyright: Fairtrade Finland)

Despite their self-determination, Southern producers do not live in a social vacuum.

Fairtrade Finland revealed the conditions that shaped the producer-driven development through relating the realities of their lives (see Goodman, 2010; Hudson and Hudson, 2003). The posts varied from statements of fact, such as 'There are about 25 million coffee farmers in the world. Most coffee is grown on family farms' and characterizations of the problems faced by producers, such as 'Over a half of Fairtrade farmers live in the lowest income countries where an average income totals less than one euro per day'. The descriptions of such struggles were commonly followed by presentations of particular Fairtrade principles that were devised to remedy such challenges: 'Fairtrade banana growers are paid guaranteed Fairtrade price which covers 
the costs of sustainable production and varies from country to country'. Consequently, producers emerged as autonomous agents actively working towards improving their livelihoods (see Adams and Raisborough, 2008) with the support of Fairtrade (e.g., 'The Fairtrade system prohibits the exploitation of child labour, and the Fairtrade's contribution to the increasing family income makes it possible for more and more children to have access to school'). In this constellation, Fairtrade is only an instrument, that is, a helper (Bal, 1997), that enables producers to support themselves, their families and their communities.

Consumers are also occasionally addressed as helpers in improving the livelihoods of producers. Such posts highlighted their general potential to support producers: '[F]air buying decisions are reflected in the lives of smallholders in 19 countries in Africa, South America and Asia'. Moreover, they presented specific cases in which this potential was realized: 'If you ever bought Kenyan Fairtrade flowers, you might have contributed to funding the construction of this well. Thanks for that!' The latter quote illustrated a rare instance of replacing third-person narration with second-person narration, which emphasized the role of Fairtrade Finland as a mediator between producers and consumers (see Barnett et al., 2005: 34). Encouraging consumers to imagine themselves as assisting underprivileged others in faraway places carries the risk of commodifying producers through belittling their agency in favour of emphasizing the role of the consumer (see Lyon, 2006; Varul, 2008). Nevertheless, Fairtrade Finland 
avoids the commodification of producers by generally presenting them as active subjects whose achievements result primarily from their own efforts and only secondarily arise from the consumers' financial support. Moreover, the general separation of the producers' life stories from particular branded products, which Fairtrade Finland does not sell, minimizes the risk of commodifying individual biographies (see Goodman, 2004).

Overall, the narrative of the self-determining producers conveyed and reinforced the agency of Southern producers in the Fairtrade system (see Dolan, 2008; Brown, 2007). The content posted by the organization provided producers with backstories about their lived realities and the often structural problems they had to face (see Dogra, 2012). However, Southern producers were not offered the possibility to participate in the process of narration or representation. Hence, based on the results of this analysis, Fairtrade Finland does not use the unique affordances of Facebook to convey the agency of Southern producers in any novel way.

\section{The narrative of the narrating producers}

In contrast to Fairtrade Finland, Pizca del Mundo offers Southern producers varied forms of agency that largely transcend the discourse and penetrate the narration. In particular, producers motivated the narration through acting, looking and speaking (Bal, 
1997). Arguably, the porousness of the narrative enabled the emergence of the voice of distant others.

Instead of adopting the position of an external narrator, Pizca del Mundo often employed the first-person plural, therefore becoming a character in the story: 'We know that it will sound romantic and fantastic, but we REALLY search for these delicacies far-far away, in the Peruvian selva, for instance'. Thus, the brand stakes no claims to impartiality (e.g., '[Presenting Fair Trade as charity] really gets in our face too, but we thought we were in it alone).). The stories about producers become simultaneously the stories of the products and of the brand itself:

Do you know why our Peruvian coffee is so delicious? Piece of cake: all love, assiduity and care extended by the farmers that cultivate it are transferred into the soil, then make their way to the coffee seed, and get into a tiny seedling. (Pizca del Mundo, 4 March 2014)

Describing the hard physical labour in the manner of a fairy-tale carries the risk of decontextualizing and romanticizing production processes and by extension, the producers (Dolan, 2008; Ramamurthy, 2012; Varul, 2008). However, in other posts, the brand provides factual and contextualized accounts of the lived realities of Southern producers as active agents influenced by the structures of global trade. 
The discursive agency of producers was articulated in two very general posts that departed from the vision of fair trade as a charity and emphasized the capacity of producers as business partners (see Dolan, 2008):

People producing coffee, tea or cocoa thousands of kilometres away, do not care about our mercy or good will.... They simply want to be treated fairly while trading, [and for us] not to overuse our privileged position.... They want to live decently on their work, not on our alms. (Pizca del Mundo, 18 August 2013)

Thus, producers were portrayed as active agents who were capable of shaping their own lives despite the unjust structures of global trade (see Adams and Raisborough, 2008). These posts stressed that the agency of producers was influenced by their material poverty, which obscured the fundamental similarities between Southern producers and Northern consumers: 'They want their children to have the same opportunities as our children have.... They want to live, work, love and study - the starting point is to understand that they are exactly the same as we are!'

The discursive agency of producers was concretized in posts about specific farmers performing particular activities on agricultural fields, such as 'meticulously preparing new seedlings, which is important at the outbreak of the la roya fungus in Peru'. In these posts, the agency of the producers was apparent at the narrative level of the story. It was articulated not only in their representations but also through actions that 
motivated — rather than illustrated, as in the case of Fairtrade Finland - the narration. By presenting producers as agents who actively dealt with their predicament through concrete everyday activities, Pizca del Mundo transformed fair trade producers from the emblematic 'deserving' poor (Adams and Raisborough, 2008) to embodied characters who were located in concrete places and situations (Bal, 1997; Couldry, 2010).

The close examination revealed that the producers themselves were the direct sources of knowledge, and their gaze frequently motivated the narration. Pizca del Mundo often shared mainly visual content that producer organizations, most notably their major coffee supplier in Peru, posted on their own Facebook pages. Consequently, producers were offered narrative agency to prompt relevant topics. For example, the outbreak of coffee leaf rust and the subsequent attempts to restore the plantation featured prominently in the content shared by Pizca del Mundo, as did the technological development of the co-operative: 'Thanks to the purchase of new machines (partly financed by the Fairtrade premium), the productivity of the processing plant has grown by $500 \%$ '. Such posts presented Southern agriculture as an industrial processing enterprise, not a backward effort of individual peasants (Berlan, 2008; Brown, 2007; Ramamurthy, 2012; Varul, 2008). Enabled by the technological affordances of Facebook, the sharing of content generated by distant others partially reverses the portrayal of fair trade producers as objects of the consumers' gaze (Ramamurthy, 2012) 
to subjects who look, see and represent their lived reality through digital storytelling (Couldry, 2008; Mitra, 2001).

The posts generated by producer organizations consisted of not only photos but also brief comments written in Spanish. Because of the perceived need for translation or the willingness to provide consumers with additional context, that is, a 'thicker' description (Goodman, 2010; Hudson and Hudson, 2003), the brand usually elaborated the original captions. For instance, a photo described by the co-operative simply as '[o]ur new nursery facilities' (see Figure 2) was supplemented by Pizca del Mundo with a backstory about the fungus outbreak and the struggles of organic farmers to tame it:

We have mentioned that a coffee fungus, cutely named La Roya, rages about in Latin America, haven't we? Conventional farms handle it more easily [by] treating fungus with chemicals. Organic farms, and those prevail in Peru, incur massive losses. Some farmers had to cut up to a half of their bushes. New [bushes] will only fructify in three years. And this is how the preparations look; in the photo a plantation of new seedlings in our co-operative. (Pizca del Mundo, 16 January 2014) 




Figure 2. New nursery facilities (copyright: Central Unitaria de Asociaciones Agraria Villa Rica)

This high degree of mediation inhibited the voice of producers, yet it incorporated their viewpoint into the narration.

The viewpoint of producers was even more explicit in a post that recounted a personal meeting with the executive director of the Peruvian coffee co-operative:

Two days ago in Lima, we met with the director of the Cunavir co-operative, Noe. He confirmed that [coffee seedlings] were relatively grown already, and that despite the social problems in the region, everything was going in the right direction. (Pizca del Mundo, 20 October 2013)

Although this post focused on the process of growing coffee, it also provided some information about the social issues afflicting the region. Thus, the context of coffee production, which was relevant from the producers' point of view, was revealed (see Hudson and Hudson, 2003). 
Overall, the analysis found that Pizca del Mundo’s Facebook page presented an environment that was potentially conducive to the emergence of the voice of distant others. Producers were presented as embodied subjects with viewpoints and the narrative agency to articulate their views. Indeed, the voice of distant others resounded in three posts.

Two of these posts were similar because they both featured the video of a female representative of a Southern producer association, one in Kenya and the other in Peru. The representatives spoke about the goals and achievements of their organizations. The first video was re-posted by the brand without any comment, and the second video included only a short introduction of the speaker. I maintain that these posts offered a genuine voice to distant others because they corrected the Northern-centrism of the conventional fair trade discourses (see Dolan, 2008). Thus, through the mouth of their representative, the disabled Kenyan artisans spoke about themselves as empowered business people, not grateful beneficiaries (see Lekakis, 2013; Wheeler, 2012). Moreover, the term shortening the distance referred not only to the consumers who learnt about the life stories of producers but also to the producers who appreciated an opportunity to 'see the face of the consumer [as a person] with feelings and emotions'. The executives of the producer organizations effectively become the internal narrators of the story and characters with names, faces and voices. Importantly, their voices were not restricted to talking about their organizations and personal experiences but 
articulated matters concerning Northern consumers as well as the broad topics of politics and global trade (e.g., 'To the European Parliament, I would tell them to also inculcate... policies concerning fair trade products. And they should be ambassadors for what fair trade is all about. Because we need to be fair, even as we do trade globally').

In the third post, which contained the link to a co-operative's website, a quote from this website and a comment by the Pizca del Mundo ('Get to know those who work for many months so that we... can enjoy the best coffee'), the voice of producers was confined to written text. According to the quote from the website, 'The Cooperativa contributes to a better use of environmental, financial and human resources in order to improve the quality of life for our families and the quality of coffee produced in our region of Copan - actions that [conjointly support the development of our nation]'. This self-presentation cast new light on the role of the Southern producer organization: rather than describing their work exclusively in terms of the provision of products for the Northern consumers' pleasure, the producers emphasized that the production of quality coffee served to upgrade the living standards of their families and ultimately of the whole nation. Furthermore, by referring to the 'better use' of resources, the co-operative positioned itself as an able manager, thus refuting the vision of fair trade producers as backward peasants (see Ramamurthy, 2012; Varul, 2008). 
In summary, not only did Pizca del Mundo present Southern producers as agents who actively shaped their lives (discursive agency) but also provided them with the potential to influence the narration through the mediated representations of their daily lives (narrative agency). The narrative agency of the producers was manifest in actions that motivated the narration as well as in their gaze, which both captured the world around them and suggested topics to be addressed. In addition, the voice of the producers emerged on three occasions with their speaking authority extended not only to talking about themselves but also to challenging the conventional Northern-centrism of fair trade discourses.

\section{Proper distance in the Facebook narratives of producers}

Considering the potential of the internet to include distant and marginalized others (Madianou, 2013; Mitra, 2001, 2004) and to extend the telling of stories beyond the cardboard cuboid of a coffee or tea box (see Couldry, 2008), I analysed the content of Facebook posts by Fairtrade Finland and Pizca del Mundo to determine how they mediated the agency of Southern producers through the content posted on their Facebook page. In analysing the use Facebook as a channel of fair trade communication, it was vital to contemplate the identified narratives from the perspective of proper distance (see Chouliaraki, 2011; Silverstone, 2003, 2007). As I previously argued, the general failure of conventional fair trade representations to 
'shorten the distance' results from the insufficient depiction of the similarities (agency), and/or the inadequate elaboration of the differences (circumstances shaping this agency) between producers and consumers.

Fairtrade Finland presented Southern producers as hardworking subjects (see Adams and Raisborough, 2008; Luetchford, 2008) whose agency resided in actively improving their livelihoods and in shaping the development of their communities. Their agency was a part of their daily lives as conveyed in the discourse employed by Fairtrade Finland. However, the producers were offered no means of participating in the narration process. Furthermore, the deployment by Fairtrade Finland of representations similar to those criticized for commodifying producers, such as individual portraits of smiling producers, threatened the proper distance (Dolan, 2008; Ramamurthy, 2012; Varul, 2008).

Nevertheless, in most instances, Fairtrade Finland presented Southern producers from the proper distance, which was achieved by representing them not as grateful beneficiaries but as autonomous agents who were capable of improving their livelihoods with the modest financial support of consumers and the organizational facilitation of the Fairtrade system. Although the photos portrayed producers either as wearing native clothes or located in somewhat exotic settings (see Ramamurthy, 2012; Varul, 2008), their activities were mundane and easily identifiable or described in the posts. Even 
though the faces of the producers were often brightened by their smiles, they were not romanticized by concealing the hardships of their daily lives (Lekakis, 2013; Ramamurthy, 2012; Wheeler, 2012), which were usually revealed in the accompanying texts about the issues and structural inequalities that negatively affected the livelihoods of producer communities. Moreover, the continuity of Facebook storytelling renders the rare disturbances of proper distance in any single post less damaging than in the case of representations used in short-lived marketing campaigns or in point-of-sale materials. Generally, Fairtrade Finland used Facebook as a tool to build ethical relationships with distant others through providing consumers with the 'thick description' of the producers' lives and realities (see Frosh, 2011; Goodman, 2010), which differed from the traditional channels of fair trade communication only in its continuity and (relatively) unlimited space.

Pizca del Mundo also mediated the agency of producers through the discourse employed to tell stories about them, but it also offered them the possibility of participating in the narration. In effect, a considerable portion of the content curated by Pizca del Mundo related to the posts generated by producer organizations. Thus, the brand told the story largely from the perspective of insiders' experiences and perceptions. Furthermore, in three posts, the representatives of producer organizations 'spoke' to consumers in their own voices. 
These new possibilities for producers to represent themselves undoubtedly democratized the narrative, but they also problematized the preservation of proper distance. The proper distance requires a certain degree of mediation to ensure the representation of distant others in both their similarity, here conceptualized as agency, and difference, which is understood as the context that shapes this agency (see Silverstone, 2003, 2007). Pizca del Mundo usually translated or expanded the content generated by producer organizations, yet on two occasions, it abstained from doing so to the detriment of the proper distance. In the first case, the Southern producer appeared as a decontextualized prop: a photo of an exotic man smiling at the camera while performing an unidentifiable activity in the tropical nature of Ethiopia was shared in the middle of the Polish winter without any comment or description. The differences between the Ethiopian producer and Polish consumers were glaring but unexplained, and his agency was confounded by his smile and puzzling behaviour (see Ramamurthy, 2012). The unmediated distance disenabled understanding. The second instance of refraining from mediation was an untranslated post in Spanish about a commercial fair in Peru: the lack of context in conjunction with linguistic distance disenabled the intended representation of Southern producers as business people.

Hence, the inclusion of distant others in the process of narration is a double-edged sword. When it is executed properly, it can enhance the agency of Southern producers. However, if it is performed without appropriate mediation, it can widen the gap between 
the audience and distant others. Endowing producers with the agency to represent and speak for themselves does not diminish the responsibility of the organization for the portrayal of the distant other (Silverstone, 2002). Instead, if distant others can 'speak' in the narrative (see Spivak, 1993), the responsibility for their appropriate re-presentation ultimately falls on fair trade organizations as mediators (see Goodman, 2010; Hudson and Hudson, 2003).

\section{Conclusions}

This paper used narratology to analyse representations of Southern producers posted by Fairtrade Finland and Pizca del Mundo on their Facebook pages. The differences between the identified narratives could be explained by the distinct objectives that each organization had in using Facebook. Whereas Fairtrade Finland attempted to reinforce the credibility of the system it coordinates through telling success stories about producers, Pizca del Mundo strove to stimulate the demand for fair trade products through re-telling the stories that producers told about themselves. Such re-telling served both to bring the figure of the producer into consumers' minds and to reassure consumers about the quality of the fair trade products.

The mode of representation advocated in this paper is predicated upon conveying the agency of distant others and revealing the post-colonial relationships that shape this agency. Such representations are in line with the imperative of 'proper distance' 
(Silverstone, 2003, 2007) to present distant others in both their shared humanity and difference. By introducing the concept of proper distance into the analysis of fair trade representations, this paper provided an empirical contribution to the largely theoretical literature on proper distance (see Hull and Stornaiuolo, 2014). It also problematized the idea of 'shortening the distance' between producers and consumers, which both industry and academic discourses on fair trade appear to have taken for granted.

It must be acknowledged that representation is a highly contested 'genre' of fair trade communication. On one hand, the dissemination of knowledge about and representations of Southern producers is considered vital in building consumer support for fair trade (Goodman, 2010; Hudson and Hudson, 2003). On the other hand, there is little evidence to prove that it has any effect on purchasing decisions (see Levi and Linton, 2003; Low and Davenport, 2007). Because they are well aware of this limitation, Fairtrade Finland and Pizca del Mundo utilize the interactive and dialogical features of Facebook to establish a relationship between themselves and consumers, not between the producers and consumers, through competitions, raffles and so on (2015, personal communication). Although the effect on consumers of the representations of Southern producers as active agents remains to be studied empirically, this paper posits that they are important not as a means of boosting sales but as an instrument of a moral education that aims to render the predicament of distant others as worthy of attention, emotion and action (Chouliaraki, 2008). 
Finally, this paper considered the potential of Facebook to educate Northern publics about distant others. Because the discussion has focused on the traditional media (e.g. Chouliaraki, 2006, 2008, 2011; Frosh, 2011; Wright, 2011), social media remains overlooked although it offers new ways of representing distant others from the proper distance, including the potential for their self-representation. On Facebook, distant others can exercise at least some control over their representations, whereas this possibility is absent in the traditional media (Wright, 2011). Furthermore, when Southern producers are endowed with narrative agency, Facebook can provide a steady flow of first-hand knowledge about producers and their lived realities to support the cumulative building of a moral relationship between the audience and distant others (Frosh, 2011).

Funding

This research was funded by the Finnish Cultural Foundation.

\section{References}

Adams M, Raisborough J (2008) What can sociology say about Fair Trade? Class, reflexivity and ethical consumption. Sociology 42(6): 1165-1182.

Bal M (1997) Narratology: introduction to the theory of narrative ( $2^{\text {nd }}$ ed.). Toronto: University of Toronto Press. 
Barnett C, Cloke P, Clarke N and Malpass A (2005) Consuming ethics: articulating the subjects and spaces of ethical consumption. Antipode 37(1): 23-45.

Berlan A (2008) Marketing of fair trade cocoa from Ghana. In: De Neve, G, Luetchford, P, Pratt J and Wood EC (eds.) Hidden hands in the market: ethnographies of fair trade, ethical consumption, and corporate social responsibility. Research in Economic Anthropology (28). Bingley: JAI Press, pp. 171-194.

Brown MB (2007) 'Fair Trade' with Africa. Review of African Political Economy 34(112): 267-277.

Bryant RL, Goodman MK (2004) Consuming narratives: the political ecology of 'alternative' consumption. Transactions of the Institute of British Geographers 29(3): 344-366.

Chouliaraki L (2006) The spectatorship of suffering. London: SAGE.

Chouliaraki L (2008) The media as moral education: mediation and action. Media, Culture and Society 30(6): 831-852.

Chouliaraki L (2010) Ordinary witnessing in post-television news: towards a new moral imagination. Critical Discourse Studies 7(4): 305-319.

Chouliaraki L (2011) 'Improper distance': towards a critical account of solidarity as irony. International Journal of Cultural Studies 14(4): 363-381.

Couldry N (2008) Mediatization or mediation? Alternative understandings of the emergent space of digital storytelling. New Media and Society 10(3): 373-391.

Couldry N (2010) Why voice matters. London: SAGE. 
Culler J (2001) The pursuit of signs. London: Routledge.

Dayan D (2007) On morality, distance and the other: Roger Silverstone's Media and Morality. International Journal of Communication 1(1): 113-122.

Dogra N (2012) Representations of global poverty: aid, development and international NGOs. London: IB Tauris.

Dolan CS (2008) In the mists of development: Fairtrade in Kenyan tea fields. Globalizations 5(2): 305-318.

Fisher C (2007) Selling coffee, or selling out? Culture and Agriculture 29(2): 78-88.

Frosh P (2011) Phatic morality: television and proper distance. International Journal of Cultural Studies 14(4): 383-400.

Goodman MK (2004) Reading Fair trade: political ecological imaginary and the moral economy of Fair trade goods. Political Geography 23(7): 891-915.

Goodman MK (2010) The mirror of consumption. Geoforum 41(1): 104-116.

Hudson I, Hudson M (2003) Removing the veil? Commodity fetishism, Fair trade, and the environment. Organization and Environment 16(4): 413-430.

Hull GA, Stornaiuolo A (2014) Cosmopolitan literacies, social networks, and "proper distance". Curriculum Inquiry 44(1): 15-44.

Krier J-M (2008) Fairtrade 2007. Culemborg: DAWS (accessed 28 June 2016). Available at: 
http://www.fairtrade.org.pl/materialy/publ_17_fairtrade2007newfacts+figurespdf.p df.

Lekakis E (2013) Coffee activism and the politics of Fair trade and ethical consumption in the global north. New York: Palgrave Macmillan.

Le Velly R (2007) Is large-scale Fair trade possible? In: Zaccai E (ed.) Sustainable consumption, ecology and Fair trade. London: Routledge, pp. 201-215.

Levi M, Linton A (2003) Fair trade: a cup at a time? Politics \& Society 31(3): 407-432.

Linklater A (2007) Distant suffering and cosmopolitan obligations. International Politics 44(1): 19-36.

Low W, Davenport E (2007) To boldly go ... Exploring ethical spaces to re-politicise ethical consumption and Fair trade. Journal of Consumer Behaviour 6(5): 336-348.

Luetchford P (2008) The hands that pick fair trade coffee. In G De Neve, P Luetchford, J Pratt, and DC Wood (eds). Hidden Hands in the Market: Ethnographies of Fair Trade, Ethical Consumption, and Corporate Social Responsibility. Research in Economic Anthropology (28). Bingley: JAI Press, pp. 143-169.

Lyon S (2006) Evaluating fair trade consumption: politics, defetishization and producer participation. International Journal of Consumer Studies 30(5): 452-464.

Madianou M (2013) Humanitarian campaigns in social media. Journalism Studies 14(2) 249-266. 
Madianou M, Longboan L and Ong JC (2015) Finding a voice through humanitarian technologies? Communication technologies and participation in disaster recovery. International Journal of Communication 9: 3020-3038.

Mitra A (2001) Marginal voices in cyberspace. New Media and Society 3(1): 29-48.

Mitra A (2004) Voices of the marginalized on the internet: examples from a website for women of South Asia. Journal of Communication 54(3): 492-510.

Mitra A, Watts E (2002) Theorizing cyberspace: the idea of voice applied to the internet discourse. New Media and Society 4(4): 479-498.

Moberg M, Lyon S (2010) What's fair? The paradox of seeking justice through markets. In S Lyon and M Moberg (eds.) Fair Trade and Social Justice. New York: New York University Press, pp. 1-23.

Orgad S (2012) Media representation and the global imagination. Cambridge: Polity.

Orgad S and Seu IB (2014) The mediation of humanitarianism: toward a research framework. Communication, Culture and Critique 7(1): 6-36.

Pizca del Mundo (n.d.) In Facebook [Fan page] (accessed 8 March 2016). Available at: https://www.facebook.com/PizcaDelMundo.

Polakom nie zależy na Trzecim Świecie, wolimy kupować taniej [Poles do not care about the Third World, we would rather pay less] (2012) Gazeta Wyborcza (accessed 28 June 2016). Available at: http://pieniadze.gazeta.pl/Gospodarka/1,125292,11230688,Polakom_nie_zalezy_na _Trzecim_Swiecie_wolimy_kupowac.html 
Radziukiewicz M (2013) Postrzeganie idei Sprawiedliwego Handlu - zachowania i postawy polskich konsumentów [Perception of Fair Trade - behaviours and attitudes of Polish consumers] (accessed 28 June 2016). Available at: fhttp://ibrkk.pl/f/?Radziukiewicz-Raport-handel-wewnetrzny-2013.pdf

Raghuram P, Madge C and Noxolo P (2009) Rethinking responsibility and care for a postcolonial world. Geoforum 40(1): 5-13.

Ramamurthy A (2012) Absences and silences: the representation of the tea picker in colonial and fair trade advertising. Visual Culture in Britain 13(3): 367-381.

Raynolds, LT (2002) Consumer/producer links in Fair trade coffee networks. Sociologia ruralis 42(4): 404-424.

Raynolds LT (2008) Mainstreaming Fair trade coffee: from partnership to traceability. World Development 37(6): 1083-1093.

Reilu kauppa (2016) Vuosiraportti 2015 [Annual report] (accessed 28 June 2016). Available at: http://www.reilukauppa.fi/fileadmin/user_upload/reilukauppa/Tilattavat_materiaalit /Reilu_kauppa_ry_vuosiraportti_2015.pdf.

Reilu kauppa (n.d.) In Facebook [Fan page] (accessed 8 March 2016). Available at: https://www.facebook.com/reilukauppa.

Shreck A (2005) Resistance, redistribution, and power in the Fair trade banana initiative. Agriculture and Human Values 22(1): 17-29. 
Silverstone R (2002) Complicity and collusion in the mediation of everyday life. New Literary History 33(4): 761-780.

Silverstone R (2003) Proper distance: toward an ethics for cyberspace. In: Liestøl G, Morrison A and Rasmussen T (eds.) Digital media revisited: theoretical and conceptual innovations in digital domains. Cambridge, Mass: MIT Press, pp. 469490.

Silverstone R (2007). Media and morality. Cambridge: Polity Press.

Silverstone R (2008) Media and communication in globalised world. In: Barnett C, Robinson J and Rose G (eds.) Geographies of globalisation: a demanding world. London: SAGE, pp. 55-94.

Spivak GC (1993) Can the subaltern speak? In: Williams P and Chrisman L (eds.) Colonial discourse and post-colonial theory: a reader. Hemel Hempstead: Harvester Wheatsheaf, pp. 66-111.

Tallontire A (2009) Top heavy? Governance issues and policy decisions for the fair trade movement. Journal of International Development 21(7): 1004-1014.

Varul MZ (2008) Consuming the campesino. Cultural Studies 22(5): 654-679.

Wheeler K (2012) 'Change today, choose Fairtrade': Fairtrade fortnight and the citizenconsumer. Cultural Studies 26(4): 492-515.

Wright C (2004) Consuming lives, consuming landscapes. Journal of International Development 16(5): 665-680. 
Wright K (2011) Listening to suffering: what might 'proper distance' have to do with radio news? Journalism 12(6): 1-19. 